RESEARCH REPORT

\title{
Long term effect of breast feeding: cognitive function in the Caerphilly cohort
}

\author{
P C Elwood, Janet Pickering, J E J Gallacher, Janie Hughes, David Davies
}

J Epidemiol Community Health 2005;59:130-133. doi: 10.1136/jech.2004.022913

See end of article for authors' affiliations

Correspondence to:

Professor P Elwood, MRC Unit, Llandough Hospital, Penarth CF64 2XW, UK. pelwood@doctors.org.uk

Accepted for publication 20 June 2004
Study objective: There is evidence suggesting that artificial feeding is associated with a reduction in cognitive function in infants and children, in contrast with breast feeding, but the available evidence suffers from confounding by social and educational factors. An opportunity arose in the Caerphilly cohort study to examine relations between cognitive function in older men and their feeding as infants, when breast feeding was usual.

Design: A prospective cohort study.

Setting: Caerphilly, South Wales, UK, was a deprived coal mining community when the men had been born in 1920-35. Most had been breast fed as infants.

Participants: 779 men aged 60-74 years when tested. The men had earlier been asked to obtain from their mothers their birth weight, and how they had been fed as infants.

Results: Complete data were obtained for 779 men. In those whose birth weight had been at or above the median, the adjusted mean cognitive function was only slightly and non-significantly lower in those who had been artificially fed. In the men whose birth weight had been below the median, having been artificially fed was associated with significantly lower results in both a test of reasoning (the AH4) and word power (the national adult reading test (NART)). Two standard deviations below the median birth weight, artificial feeding was associated with a reduction of six points (70\% of a SD) on word power (the NART).

Conclusions: In men whose birth weight had been low, having been artificially fed is associated with poorer cognitive function in late adult life.
$\mathrm{T}$ he relevance of breast and artificial feeding to cognitive function has been long debated. In a meta-analysis ${ }^{1}$ of 20 studies of children whose cognitive function had been tested between infancy and adolescence, breast feeding was associated with significantly better cognitive performance. The benefit seemed to increase with increasing duration of breast feeding and was greatest in those whose weight at birth had been low.

The studies in this meta-analysis, ${ }^{1}$ and most of the other relevant studies, have been based on infants and young children, and it is difficult to make long term predictions from results obtained in childhood. One recent study however was based upon the testing of adults at ages 19 and 27 years and in this there was a pronounced positive association, cognitive performance increasing with longer duration of breast feeding, up to nine months. ${ }^{2}$

The hypothesis that infant feeding with cows' milk is inadequate for full cognitive development is supported by the presence in breast milk, but not cows' milk, of certain long chain polyunsaturated fatty acids that are major components of cell membranes within the central nervous system. ${ }^{3}$ These are essential for preterm infants, ${ }^{4}$ and an overview of randomised controlled trials has shown benefit from supplementation in term infants. ${ }^{5}$ Until very recently, none of these nutrients have been added to any formula milk. ${ }^{6}$

The evaluation of infant feeding is difficult, particularly in recent studies in industrialised countries, because of pronounced confounding between the method of feeding, breast or artificial, and social, educational, emotional, and other factors relevant to general child care and child development. During the past 20 or 30 years, mothers who have chosen to breast feed are likely to have been, on average, the more advantaged, and probably the more health conscious. Furthermore, while factors such as these operate primarily during infancy, a mother who has breast fed may go on to instil beneficial lifelong health and social behaviours in her offspring.

On the other hand, in earlier years, when breast feeding was the standard method of infant feeding, and artificial feeding much less prevalent, a mother's choice of feeding method for her infant was unlikely to have been seriously biased by social and educational factors. ${ }^{78}$ Of particular interest, therefore, are the associations between breast or artificial feeding and the cognitive function of older persons.

This report is based on the results of cognitive function tests in a large population sample of older men. The aim was to compare the cognitive function of men who had been breast fed or artificially fed as infants from a comparison of cognitive tests. The men had already obtained from their mothers whether or not they had been breast fed and the duration of breast feeding if appropriate.

\section{METHODS}

The Caerphilly cohort study, which was set up in 1979-83, was based on men born between 1920 and $1935 .{ }^{9}$ In 1994-8, the men were aged 60-74 years, each was asked to do a number of tests of cognitive function. The tests were undertaken in a quiet room at home by a specially trained technician. ${ }^{10}{ }^{11}$

The tests were:

- The national adult reading test (NART) tests a subject's knowledge of words. The results indicate pre-morbid IQ, that is general cognitive function before any decline attributable to age or disease. ${ }^{12}$

Abbreviations: NART, national adult reading test; CRT, choice reaction time 
- The AH4 ${ }^{13}$ tests verbal and mathematical reasoning in a series of questions presented on a computer screen. The number of questions answered correctly within the first 10 minutes is used as a measure of general intelligence.

- The choice reaction time (CRT) measures hand-brain reaction speed. Visual stimuli are presented on a computer screen and the subject has to press an appropriate button on a four button keyboard. The mean delay is used as a measure of the speed of reaction.

The tests of cognitive function were undertaken twice, with a five year interval. Most of the men were totally unfamiliar with such tests, and many had never used a keyboard or computer before. We have therefore based this report on analyses of the second tests, to reduce differences in men in the use a keyboard and responding to a computer screen.

The men had already been asked to obtain from their mothers, if still alive, their birth weight, whether or not they had been breast fed and if so, for how long.

Analysis of the associations between infant feeding and cognitive function was by multiple linear regression, adjusting for possible confounding. Factors for which adjustments were made related to the subjects themselves (age, social class, education, and birth order), and related to conditions during the man's childhood (parental social class, the number of siblings, and unemployment of his father for a year or more while the subject had been aged under 10 years).

\section{RESULTS}

The Caerphilly cohort study has many objectives, the main ones being relevant to vascular disease. Cognitive function tests performed by the men when aged 60 to 74 years are used in this report.

Altogether 1701 men attended the main clinics and a further 209 men were seen at home (93\% of the survivors of the original cohort). Of these, 1220 (66\%) completed the cognitive function tests satisfactorily. Information on how these men had been fed as infants had already been obtained from the mothers of $64 \%$ of the men with cognitive function data (779 men). Of these, 593 (76\%), had been breast fed and $186(24 \%)$ had been artificially fed. It had not been possible to ascertain the duration of breast feeding of $222(37 \%)$ of the men.
Table 1 summarises data on social and other factors that could confound the relations of interest. On the whole, differences between men who had been breast fed, and men who had been artificially fed, are small. The most important difference is that the men who were breast fed had been significantly heavier at birth than the men artificially fed, by

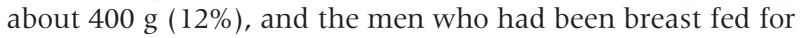
three months or more had been $450 \mathrm{~g}$ (14\%) heavier than those who had been fed artificially. Birth weight is therefore treated as an important confounding factor and relations are presented within two subgroups, namely those who had been above the median birth weight, and those who had been at or below the median (3.56 kg or $7 \mathrm{lb} 13.5 \mathrm{oz}$ ). Adjustments are made for differences in social class, education, birth order, and family size as well as for paternal social class and unemployment of the fathers.

In table 2 the mean test scores are shown for groups of men subdivided by both how they had been fed as infants, and their birth weight. The table also shows the differences in means between the scores for men who had been breast fed and the scores in those who had not been breast fed. These differences have been obtained from multiple regression analyses, adjusted for a large number of possible confounding factors, as shown in the footnote to the table.

After adjustment for the age of the men, their social class, education, birth order, and family size, plus their father's social class, and unemployment, those whose birth weight had been above the median show very little effect of how they had been fed as infants. For the men whose birth weights were on the median or below, there are however differences, all of which favour breast feeding. For both the test of word power (NART) and of verbal and numeric reasoning (AH4), the differences are large and significant in the men for whom the duration of breast feeding is known. There is also a suggestion that the longer breast feeding was maintained, the greater the difference, although this effect is not statistically significant. The CRT also shows differences favourable to breast feeding (that is, shorter reaction times) although the differences are not significant within any subgroup of men. In the men for whom the duration of breast feeding is unknown, the differences are all favourable, though none is significant.

The effect of birth weight on the relation between cognitive function and breast feeding is likely to be continuous, and furthermore, the effect can reasonably be assumed to be

Table 1 Characteristics of the men in the cohort subdivided by how they had been fed as infants

\begin{tabular}{|c|c|c|c|c|c|c|}
\hline & \multirow[b]{2}{*}{ Not breast fed } & \multirow[b]{2}{*}{$\begin{array}{l}\text { Any breast feeding } \\
\text { (significance*) }\end{array}$} & \multicolumn{4}{|c|}{ Duration of breast feeding } \\
\hline & & & Unknown & $\begin{array}{l}\text { Under } \\
3 \text { months }\end{array}$ & $\begin{array}{l}3 \text { months } \\
\text { or more }\end{array}$ & $\begin{array}{l}\text { Significance of } \\
\text { trendt }\end{array}$ \\
\hline Numbers of men & 186 & 593 & 222 & 125 & 246 & \\
\hline Manual work & $62 \%$ & $60 \%(p=0.62)$ & $66 \%$ & $60 \%$ & $55 \%$ & $p=0.32$ \\
\hline \multicolumn{7}{|l|}{ Education } \\
\hline Primary only & $43 \%$ & $47 \%$ & $49 \%$ & $45 \%$ & $45 \%$ & \\
\hline A higher level & $20 \%$ & $24 \%(p=0.14)$ & $22 \%$ & $22 \%$ & $26 \%$ & $p=0.37$ \\
\hline \multicolumn{7}{|l|}{ Birth order } \\
\hline First & $41 \%$ & $34 \%$ & $30 \%$ & $41 \%$ & $34 \%$ & $p=0.46$ \\
\hline Fourth or later & $22 \%$ & $26 \%(p=0.08)$ & $33 \%$ & $20 \%$ & $23 \%$ & \\
\hline Family size over four children & $46 \%$ & $59 \%(p=0.002)$ & $61 \%$ & $57 \%$ & $57 \%$ & $p<0.04$ \\
\hline Mean birth weight $(\mathrm{kg})$ & 3.35 & $3.75(p=0.0005)$ & 3.76 & 3.65 & 3.79 & $p<0.0005$ \\
\hline Leisure activity ( $\mathrm{kJ} /$ day) & 0.53 & $0.59(p=0.25)$ & 0.57 & 0.62 & 0.58 & $p=0.36$ \\
\hline \multicolumn{7}{|l|}{ Smoking } \\
\hline Non-smoker & $22 \%$ & $19 \%$ & $18 \%$ & $17 \%$ & $20 \%$ & \\
\hline Ex smoker & $42 \%$ & $50 \%$ & $48 \%$ & $48 \%$ & $53 \%$ & $p=0.20$ \\
\hline Current & $35 \%$ & $31 \%(p=0.20)$ & $34 \%$ & $34 \%$ & $27 \%$ & \\
\hline \multicolumn{7}{|l|}{ Father } \\
\hline Manual & $91 \%$ & $87 \%(p=0.22)$ & $84 \%$ & $88 \%$ & $90 \%$ & $p=0.78$ \\
\hline Unemployed for one year or more & $40 \%$ & $45 \%(p=0.16)$ & $45 \%$ & $40 \%$ & $45 \%$ & $p=0.50$ \\
\hline
\end{tabular}


Table 2 Mean cognitive function (SD) and infant feeding as infants in men subdivided at the median birth weight (3.56 kg)

\begin{tabular}{|c|c|c|c|c|c|c|c|}
\hline & \multicolumn{4}{|c|}{ Mean (SD) test scores } & \multicolumn{3}{|c|}{$\begin{array}{l}\text { Adjusted differences* between the mean scores in men breast fec } \\
\text { and men artificially fed }\end{array}$} \\
\hline & $\begin{array}{l}\text { Artificially } \\
\text { fed }\end{array}$ & $\begin{array}{l}\text { Breast fed } \\
\text { duration } \\
\text { unknown }\end{array}$ & $\begin{array}{l}\text { Breast fed less } \\
\text { than three } \\
\text { months }\end{array}$ & $\begin{array}{l}\text { Breast fed for } \\
\text { more than three } \\
\text { months }\end{array}$ & $\begin{array}{l}\text { Breast fed, duration } \\
\text { unknown, and none }\end{array}$ & $\begin{array}{l}\text { Breast fed less } \\
\text { than three months, } \\
\text { and none }\end{array}$ & $\begin{array}{l}\text { Breast fed three } \\
\text { months or more, } \\
\text { and none }\end{array}$ \\
\hline $\begin{array}{l}\text { Birth weight } \\
\text { above median } \\
\text { NART }\end{array}$ & $\begin{array}{l}n=49 \\
108.3(8.1)\end{array}$ & $\begin{array}{l}n=41 \\
107.7(8.9)\end{array}$ & $\begin{array}{l}n=42 \\
108.7(7.8)\end{array}$ & $\begin{array}{l}n=109 \\
109.3(8.9)\end{array}$ & $\begin{array}{l}1.9(-1.2 \text { to } 5.1) \\
p=0.22\end{array}$ & $\begin{array}{l}1.7(-1.4 \text { to } 4.8) \\
p=0.28\end{array}$ & $\begin{array}{l}1.2(-1.5 \text { to } 3.8) \\
p=0.39\end{array}$ \\
\hline $\mathrm{AH} 4$ & $28.5(9.8)$ & $28.0(9.3)$ & $26.7(10.6)$ & $29.7(11.3)$ & $\begin{array}{l}1.8(-1.8 \text { to } 5.5) \\
p=0.32\end{array}$ & $\begin{array}{l}0.3(-3.5 \text { to } 4.1) \\
p=0.87\end{array}$ & $\begin{array}{l}1.8(-1.3 \text { to } 5.0) \\
p=0.25\end{array}$ \\
\hline CRT & $861(221)$ & $806(162)$ & $823(177)$ & $872(253)$ & $\begin{array}{l}-79(-171 \text { to } 13) \\
p=0.09\end{array}$ & $\begin{array}{l}-59(-149 \text { to } 32) \\
p=0.20\end{array}$ & $\begin{array}{l}-10(-93 \text { to } 72) \\
\mathrm{p}=0.80\end{array}$ \\
\hline $\begin{array}{l}\text { Birth weight } \\
\text { below median } \\
\text { NART }\end{array}$ & $\begin{array}{l}n=66 \\
105.6(9.1)\end{array}$ & $\begin{array}{l}n=34 \\
109.0(9.7)\end{array}$ & $\begin{array}{l}n=43 \\
110.1(6.9)\end{array}$ & $\begin{array}{l}n=71 \\
110.6(8.4)\end{array}$ & $\begin{array}{l}1.7(-2.0 \text { to } 5.4) \\
p=0.38\end{array}$ & $\begin{array}{l}4.3(1.4 \text { to } 7.3) \\
p=0.005\end{array}$ & $\begin{array}{l}4.7(2.1 \text { to } 7.2) \\
0<0.001\end{array}$ \\
\hline $\mathrm{AH} 4$ & $24.7(10.3)$ & $28.3(10.1)$ & $28.6(10.7)$ & $29.9(11.1)$ & $\begin{array}{l}1.7(-2.2 \text { to } 5.6) \\
p=0.39\end{array}$ & $\begin{array}{l}4.3(0.9 \text { to } 7.7) \\
p=0.01\end{array}$ & $\begin{array}{l}5.0(1.9 \text { to } 8.0) \\
p=0.002\end{array}$ \\
\hline CRT & $906(223)$ & $840(151)$ & $886(228)$ & $832(208)$ & $\begin{array}{l}-49(-140 \text { to } 42) \\
p=0.29\end{array}$ & $\begin{array}{l}-37(-120 \text { to } 46) \\
p=0.38\end{array}$ & $\begin{array}{l}-71(-144 \text { to } 2) \\
p=0.06\end{array}$ \\
\hline
\end{tabular}

*Mean differences between the groups breast fed and the group artificially fed ( $95 \%$ confidence intervals) adjusted for age, social class, education, plus the man's birth order and family size, plus his father's social class, and his father's unemployment.

curvilinear, otherwise the regression line could cross the origin and suggest that breast feeding of high weight infants is harmful to cognitive development. The overall mean NART score is 106.5 SD 9.10, and the difference between the regressions of NART score on birth weight in men who had been breast fed for three months or more and men who had not been breast fed, is described by the relation:

Reduction of NART score in men artificially fed $=42.818$ $4.885 \mathrm{ln} \mathrm{g}$ birth weight.

This implies that at around two SD below the mean birth weight, having been artificially fed is associated with a reduction of over six points on the NART (about $70 \%$ of a $\mathrm{SD})$, while at two SD above the mean birth weight, the reduction is only one NART point (about $10 \%$ of a SD).

\section{DISCUSSION}

The Caerphilly cohort has considerable advantages for this study. Caerphilly is a small industrial town and in the 1920s and 30s, the community was comparatively deprived and was fairly homogenous both socially and economically. Breast feeding was usual and artificial feeding uncommon. A report in the early $1940 \mathrm{~s}^{14}$ stated that almost three quarters of the infants in an industrial town received breast milk, and there was no difference in the household income, the housing, or the domestic hygiene relevant to these infants compared with those artificially fed. Brown et al $^{7}$ list a number of reasons why mothers did not breast feed around the same time. Almost all the reasons given were infections or chronic diseases, and none was directly social, educational, or economic.

Nevertheless, the data in table 1 show that there had been some selection within the present cohort. The lower average

\section{Key points}

- The artificial feeding of infants is associated with a reduction in cognitive function that is still apparent 60 and more years later and the effect is pronounced in subjects whose birth weight had been below average.

- The cognitive function of subjects whose birth weight had been below average was associated with a reduction of about $4 \%$. birth weight of the men who had been artificially fed suggests that they had been born into families in poorer socioeconomic circumstances than those breast fed. At the same time, the data also show that these same men came from smaller families and more of them had been first born. The combined effect of these and the other differences shown in table $l$ is therefore not easy to judge because some favoured the health and development of the breast fed infants, while other differences, such as the number first born and the numbers of siblings, are likely to have favoured the men who had been artificially fed. We have, however, adjusted for the factors that are listed above and shown at the foot of table 2 .

It is unfortunate that data are not available for the total cohort of men, and the omissions could have introduced a selection bias. At the same time, none of the factors leading to exclusion, such as unavailability of the mother or her inability to remember, or embarrassment or lack of interest on the part of the men, etc, is likely to have seriously biased the relations of interest.

A weakness in the study is uncertainty as to the validity of the data on breast feeding. There is no way in which the data supplied by the mothers of the men could be checked. However, the birth weights, which the mothers had also supplied from memory, show relations with incident vascular disease that are both in the expected direction, and of about the strength that would be predicted from published studies. ${ }^{15}$

The NART attempts to estimate performance at its peak, before there are effects of age and disease. ${ }^{12}$ This would therefore seem to be the most appropriate test in relation to the long term effects for which we are testing. Within the total group, artificial feeding is associated with a NART score that is four points lower, that is, around $50 \%$ of a SD. This is close to the estimate made by Mortensen et $a l^{2}$ in a recent study of young adults, namely lower scores in those

\section{Policy implication}

There is no adequate substitute for breast milk and no effort should be spared in promoting breast feeding. 
artificially fed by half a SD for one test, and one fifth of a SD for another test.

Our data take this further and show a relation with birth weight. An interaction with birth weight has been shown in other studies. The meta-analysis of Anderson et al suggested that the effects of artificial feeding are greater in infants born prematurely than in those born at term. Similarly, Lucas et $a l^{16}$ found that the effect of artificial feeding on cognitive performance in early childhood was more noticeable in those who had been small for gestational age. At two SDs below the mean birth weight in our cohort, artificial feeding is associated with a six point lower score on the NART (about $70 \%$ of a SD). None of this is however surprising as the rate of brain growth is greater in pre-term than in term babies.

Most of the studies reported so far have been based on

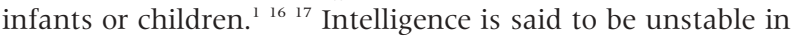
the first 10 or so years of life ${ }^{18}$ and it is possible that any apparent advantage in some of the children could simply be a consequence of psychological and other interactions between the child and its parents. The more distant from these early effects that advantage can be shown, the more likely it is that the effect is a direct consequence of developmental differences within the brain of the offspring. Our study, the first to be based on older adults, shows an effect 60 and more years after infancy, by which time any psychological or attitudinal influence from parents is likely to have become trivial.

A measure that is associated with a reduction of intelligence by anything approaching half a SD is of enormous potential detriment in almost every activity throughout the whole of life. Granted that the artificial feeds that the men in our cohort will have received will probably have been diluted sweetened cows' milk, and were therefore very different to the present day infant formula milks. Nevertheless, it is unlikely that there will ever be a fully adequate alternate for breast milk and therefore no effort should be spared in promoting breast feeding.

\section{CONTRIBUTORS}

P C Elwood: directed the Caerphilly study and the analysis of the data and has overall responsibility for the paper. Janet Pickering: analysed the data and contributed to the writing of the paper. J E J Gallacher: responsible for the collection of the cognitive function data and their interpretation. Janie Hughes: chief field worker throughout the Caerphilly study, interviewed the subjects, collected the data on breast feeding, searched the literature, and contributed to the writing of the paper. David Davies: collaborator in the study, advisor on the collection, and interpretation of the data and assisted in the writing of the paper.

\section{Authors' affiliations}

P C Elwood, J Pickering, J E J Gallacher, J Hughes, Department of Epidemiology, Statistics and Public Health, The University of Wales College of Medicine, Cardiff, UK

D Davies, Department of Child Health, The University of Wales College of Medicine

Funding: the Caerphilly study was conducted by the former MRC Epidemiology Unit (South Wales) and was funded by the Medical Research Council of the United Kingdom. The archive is now maintained by the Department of Social Medicine in the University of Bristol. Janet Pickering and Janie Hughes are supported by the Food Standards Agency.

Conflicts of interest: no author has any competing interests.

Ethical approval was sought and obtained from an appropriate ethics committee for every phase of the Caerphilly study

\section{REFERENCES}

1 Anderson JW, Johnson BM, Remley DT. Breastfeeding and cognitive development: a meta-analysis. Am J Clin Nutr 1999;70:525-35.

2 Mortensen EL, Michaelsen KF, Sanders SA, et al. The association between duration of breastfeeding and adult intelligence. JAMA 2002;287:2365-71.

3 Innis S. Perinatal biochemistry and physiology of long-chain polyunsaturated fatty acids. J Pediatr 2003;143:S1-8.

4 Gibson RA, Makrides M. Long-chain polyunsaturated fatty acids in breast milk: are they essential. Adv Exp Med Biol 2001;501:375-83.

5 Uavy R, Hoffman DR, Mena P, et al. Term infant studies of DHA and ARA supplementation on neurodevelopment: results of randomised controlled trials. J Pediatr 2003;143:S17-25.

6 Crawford MA, Costeloe K, Laurance B, et al. Breastfeeding and intelligence. Lancet 1992:339:614-16.

7 Brown RC, Dobbs R. Midwifery. London: Edward Arnold, 1946:672.

8 Mellander O, Vahlquist B, Mellbin T. Breastfeeding and artificial feeding: a clinical, serological and biochemical study of 402 infants with a survey of the literature. Acta Paediatr 1959:48(suppl): 116

9 The Caerphilly and Speedwell Collaborative Group. Caerphilly and Speedwell collaborative heart disease studies. J Epidemiology Community Health 1984;38:259-62

10 Elwood PC, Gallacher JEJ, Hopkinson CA, et al. Smoking, drinking, and other life style factors and cognitive function in men in the Caerphilly cohort. $J$ Epidemiol Community Health 1999;53:9-14.

11 Elwood PC, Pickering J, Gallacher JEJ. Cognitive function and blood rheology: results from the Caerphilly cohort of older men. Age Ageing 2001;30:135-9.

12 Nelson HE. National adult reading test (NART) manual. Windsor: NFERNelson, 1982.

13 Heim AW. AH4 group test of general intelligence ASE. Windosr: NFERNelson, 1970.

14 Deeny J, Murdock ET. Infant feeding in relations to mortality in the city of Belfast. BMJ 1944:1:146-9.

15 Frankel S, Elwood P, Sweetnam P, et al. Birthweight, body-mass index in middle age, and incident coronary heart disease. Lancet 1996;348:1478-80.

16 Lucas A, Morley R, Cole TJ. Randomised trial of early diet in preterm babies and later intelligence quotient. BMJ 1998;317:1481-7.

17 Horwood L, Darlow BA, Mogridge N. Breast milk feeding and cognitive ability at 7-8 years. Arch Dis Child $2001 ; 84: F 23-2$.

18 Schuerger JM, Witt AC. The temporal stability of individually tested intelligence. J Clin Psychol 1989;450:294-302. 